\title{
The Consolidation of Assets and Liabilities within Company Groups
}

\author{
Can South African Company Law Learn from New Zealand's Company Law?
}

Richard Stevens*

\section{Background}

The Cork Committee on Insolvency, which was tasked to investigate possible reforms in the field of insolvency law in the United Kingdom, uses the following example to illustrate the difficulties for a creditor of an insolvent group member. ${ }^{1}$ A holding company incorporates a wholly owned subsidiary company which it undercapitalises. The holding company naturally is responsible for the management of the business and affairs of the subsidiary company to the advantage of the holding company and cumulatively to the prejudice of the subsidiary company. The profits of the subsidiary company are distributed to the holding company as dividends. If the subsidiary company is in need of funding, the holding company provides the funding by means of loans. The subsidiary obtains further credit, under pressure of the holding company, and it obtains a good credit rating due to its membership of the group. The subsidiary then falls on hard times, becomes insolvent and goes into winding-up procedures. The holding company, as a concurrent creditor, at the very least, competes with the other creditors, and a substantial proportion of the subsidiary's assets goes to the holding company which naturally refused to accept any liability for the subsidiary company's debts. The Cork Committee accepted that "a law which permits such an outcome is undoubtedly a defective law". 2

The Cork Committee considered a number of 'principal ideas' ${ }^{3}$ to reform the law where insolvency within company groups occurs, especially in situations as illustrated above. The Cork Committee departed from the premise that company groups are realities of the commercial world and insolvency within groups needed to be

Senior lecturer, University of Stellenbosch; BA LLB (Stellenbosch), LLM (Tübingen) and LLD (Stellenbosch). Attorney of the High Court of South Africa.

1. The Cork Committee (Cmnd 8558), Insolvency Law and Practice: Report of the Review Committee, 1982, ch. 51, p. 435.

2. The Cork Committee supra note 1, p. 436, para. 1934

3. The Cork Committee supra note 1, p. 436, para. 1935. addressed. ${ }^{4}$ These proposals were: firstly, the joint and several liability of the companies within the group for the external debts of the other companies in the group ${ }^{5}$ secondly, an opt-in regime; ${ }^{6}$ thirdly, that there could be a contracting-out possibility in respect of the first proposal ${ }^{7}$ fourthly, liability for a company where there has been a departure from a "predetermined code of conduct"; 8 and lastly possible liability for a group member in case of the insolvency of another group member, which liability will be determined by a court, which should have a wide discretion but still within certain parameters. ${ }^{9}$ The Cork Committee ultimately made no recommendations for reform since its terms of reference were restricted to insolvency law and that any proposals regarding groups would have had an effect on other areas of the law which did not fall within its terms of reference. ${ }^{10}$

\section{Introduction}

The South African Companies Act ${ }^{11}$ (hereafter 'the Act') confirms the principle of limited liability. ${ }^{12}$ This implies that the shareholders and/or directors of the company are not automatically liable for the debts of the company. ${ }^{13}$ The Act further provides that the principle of limited liability may be ignored in particular cases. ${ }^{14}$ The principle of limited liability applies in equal measure where the shareholder of a company is another company. Where one company holds the majority of voting rights in another company, or has the power to appoint

4. The Cork Committee supra note 1, p. 434, para. 1922: “Group activity in the sense of the conduct of various businesses by a holding company through a number of subsidiaries is a twentieth century phenomenon. The principles of our company law and insolvency law were developed in the nineteenth century. It is not surprising, therefore, that some of the basic principles of company and insolvency law fit uneasily with the modern commercial realities of group enterprise."

5. The Cork Committee Report supra note 1, p. 436, para. 1935(a).

6. The Cork Committee Report supra note 1, p. 436, para. 1935(b).

The Cork Committee Report supra note 1, p. 436, para. 1935(c).

The Cork Committee Report supra note 1, p. 436, para. 1935(d).

The Cork Committee Report supra note 1, p. 436, para. 1935(e).

0. The Cork Committee Report supra note 1, p. 439, para. 1952.

. The Companies Act 71 of 2008 (the Act).

S 19(2) of the Act.

Ibid. See also A Salomon v. A Salomon \& Co Ltd 1897 AC $22(\mathrm{HL})$.

S 19(2) of the Act. See also s 20(9). 
the directors who have a majority vote on the board meetings of another company, the first mentioned company is the holding company of the second company. ${ }^{15}$ The holding company and its subsidiary company form a group of companies as defined by the Act. ${ }^{16}$ It has been argued that the application of the principle of limited liability in cases of groups of companies is a historical accident and that it should not necessarily apply where the dominant shareholder is another company. ${ }^{17}$

The problem that appears within groups is therefore that of the insolvency of one member in the group and the resulting difficulties for that member's creditors. Under the ordinary principles of company law, a creditor may only turn to his contractual debtor for the enforcement of a debt. The only circumstances where he normally could turn to its holding company, or to that debtor's fellow subsidiary, is where the holding company or fellow subsidiary, as the case may be, provided security for the debt of the debtor or bound itself as co-principal debtor to the creditor. Alternatively, the creditor will have to pierce the corporate veil between the companies within the group if there is a financially stronger group member, or attempt to prove that the defaulting group member acted as an agent for the other group member(s) or attempt to show that the companies in the group were in fact a partnership. ${ }^{18}$ These options will not be discussed as possible remedies in the light of the conclusions of Milo, but the focus will rather be on alternative remedies.

The focus of this article is not to consider the philosophical arguments in favour of treating limited liability in cases of groups of companies differently to cases where the controlling shareholder is a natural person or natural persons. ${ }^{19}$ Instead, the focus is to consider the Janse van Rensburg v. Steyn, ${ }^{20}$ Janse van Rensburg v. Botha, ${ }^{21}$ Znarts v. Fanse van Rensburg ${ }^{22}$ decisions where the consolidation of the entities within a group were ordered against the backdrop of New Zealand law where the pooling and consolidation of assets within the context of a group are possible. The New Zealand law will be evaluated and solutions be proposed to deal with the insolvency of companies within a group to better protect creditors on the assumption that they need more protection. The article is therefore written from the hypothe-

15. See s 3(1)(a) of the Act read with the definition of 'holding company' in s 1.

16. See s 1 of the Act for the definition of the concept 'group of companies'.

17. Blumberg 1993, p. 5; Muscat 1996, p. 158. For a detailed discussion of this argument, the different approaches to limited liability within the context of groups, the different philosophical considerations where there is a group and suggestions based on the piercing of the veil in the United States and the position in Germany, see Milo 1998, p. 318. See also Stevens 2011.

18. See Milo 1998, pp. 323-333.

19. In this respect see Milo 1998 and Stevens 2011

20. Janse van Rensburg $v$. Steyn (ZASCA) unreported case No 66/10 (25 May 2011).

21. Janse van Rensburg v. Botha (ZASCA) unreported case No 758/10 (25 May 2011).

22. Zwarts v. Janse van Rensburg (ZASCA) unreported case No 590/10 (25 May 2011). sis that the law as it is is inadequate to fully protect creditors of companies within a group of companies, especially undercapitalized subsidiary companies. The suggested solution is based on the principle of a pooling order but coupled with a presumption in favour of holding the holding company and/or other group members liable for the debts of the insolvent subsidiary. The article investigates whether there is a precedent in South African Law for such a presumption and concludes that section 21 of the Insolvency $\mathrm{Act}^{23}$ may serve as an example for a presumption where the assets of the holding company and/or other group members could be utilized to settle the debts of an insolvent group member.

\subsection{Fanse van Rensburg v. Steyn, Fanse van Rensburg v. Botha, and Zmarts v. Fanse van Rensburg}

The Steyn, Botha and Zmarts cases were all decided on one day by the Supreme Court of Appeal and involved the consolidation of the assets of the Krion pyramid scheme which was operated by one Prinsloo. In essence, there were four entities and a partnership and investments by the public were diverted into the four entities. Upon the liquidation of the entities, it was difficult for the liquidators of every entity to determine which entity, for example, received the investments of particular investors and whether the same entity made the repayment with interest to a specific investor. None of the entities maintained books of account, and assets and liabilities were simply transferred from one entity to the next by Prinsloo. There were close to 9,000 investors in the Krion scheme who on average invested 3.1 times each according to the court in the Steyn case. Close to 27,000 investments were made to the value of about R1.5 billion. To unravel this was an exercise in futility. Some investors received payments which the liquidators wanted to have set aside in terms of section 29 of the Insolvency $\mathrm{Act}^{24}$ on the basis that some creditors were preferred above others prior to the liquidation of the entities. Hartzenberg J ordered the consolidation of the four estates and the individual liquidators instituted legal action against some investors to recover monies in terms of the provisions of the Insolvency Act. In the Steyn and Botha cases, the courts of first instance refused to set aside the disposition to investors on the basis that there was no debtor-creditor relationship between the consolidated entity and the individual investors. In the Steyn case, the court a quo held that section 29 of the Insolvency Act required that the disposition was made by a specific debtor and that at the decisive moment the liabilities of the debtor exceeded the assets. The liquidators could not prove this since the consolidated entity did not exist at the time of the disposition and did not make the payment. One of the individual entities made the payment to Steyn. In the Botha case, the court a quo also held that the requirement of a debtor-creditor relationship was also not established by

23. Insolvency Act 24 of 1936

24. Ibid. 
the liquidators. In the Zmarts case, the court a quo found that there was a debtor-creditor relationship with the consolidated entity although the basis for the decision was not clear.

From the Botha case, it would appear that the basis for the decisions of the Supreme Court of Appeal was the doctrine of the piercing of the corporate veil in the light of the phrase 'alter ego' being used once. There is, however, neither any discussion of the tests for the piercing of the corporate veil nor of previous case law of the Supreme Court of Appeal on this topic. On the other hand, it appeared that the driving force, Prinsloo, behind the pyramid scheme maintained that the various entities were one scheme and entity. In the light of the current law, some form of piercing of the veil had to be present for the court to consolidate the liabilities of the various entities in the absence of any reference to any statutory power of the court to grant such an order.

When one considers that the South African Supreme Court of Appeal had considered the test for piercing of the corporate veil in a number of cases within the last 20 years, it was surprising that the Supreme Court of Appeal did not delve deeper into the basis for the pooling orders in these cases. Amongst others, the Supreme Court of Appeal considered in detail the test for piercing of the corporate veil in Cape Pacific Ltd $v$. Lubner Controlling Investments (Pty) Ltd ${ }^{25}$ and Hülse-Reutter and Others v. Gödde. ${ }^{26}$ Although there appears to be some confusion, especially after the Cape Pacific case as to the test for piercing of the veil, it would appear that courts would be willing to pierce the veil in cases of impropriety. The Supreme Court of Appeal mentioned in the Cape Pacific case that piercing of the veil could be allowed in cases of fraud, improper conduct or dishonesty but then later in the case refers to policy considerations and then later refers to a balance of different tests. Luiz argues that the court used policy considerations to pierce the veil. ${ }^{27}$

In the subsequent case of Hülse-Reutter and Others $v$. Gödde, ${ }^{28}$ Scott JA said the following:

The circumstances in which a court will disregard the distinction between a corporate entity and those who control it are far from settled. Much will depend on a close analysis of the facts of each case, considerations of policy and judicial judgment. Nonetheless what is, I think, clear is that as a matter of principle in a case such as the present there must at least be some misuse or abuse of the distinction between the corporate entity and those who control it which results in an unfair advantage being afforded to the latter. ${ }^{29}$

From the abovementioned cases, it does appear that some form of improper conduct would be necessary

25. 19954 SA $790(A)$.

26. 20014 SA 1336 (SCA).

27. Cilliers \& Luiz 1996, p. 53.

28. Hülse-Reutter and Others v. Gödde 20014 SA 1336 (SCA).

29. 1346A-C. before a court would be willing to pierce the corporate veil.

In the meantime, the Companies Act has introduced a provision that allows for a statutory piercing of the corporate veil. ${ }^{30}$ This provision was tested in Ex Parte Gore NO and Others. ${ }^{31}$ Section 20(9) of the Companies Act essentially provides that a court may disregard the separate juristic personality of a company where any act of the company may constitute an unconscionable abuse of the separate juristic personality of the company. The facts were very similar to the Steyn, Botha and Zwarts cases; i.e. a pyramid scheme where some investors were paid by companies within a group although those companies were not the ones which received those investors' monies. Whichever company within the group of companies could pay an investor was used to repay investors. There were no proper books of account, and monies were transferred at will between companies within the group. Due to the dysfunctional bookkeeping, it was impossible for the liquidators to identify the relevant companies against which investors had claims and therefore the question as whether the court could ignore the separate juristic personality of the subsidiary companies and thus as a result that all the assets and liabilities within the group would be those of the holding company. The court ultimately found that the company was a sham and that there was an unconscionable abuse. Unfortunately, as with the Steyn, Botha and Zwarts cases, the ex parte Gore case was a relatively easy case for a court to pierce the veil on any of the tests which have been used before, whether improper conduct, dishonesty or policy reasons. It does not therefore answer the more factual question as to when certain conduct moves within the realm of improper conduct or when an abuse of separate juristic personality becomes an unconscionable abuse. This begs the question whether the provision of pooling and/or consolidation orders like in the New Zealand Companies Act provides an answer to this question in less clear-cut cases.

Consolidation orders, however, also have some difficulties despite the apparent advantages for creditors. Questions like the effect on intra-group loans and the position of secured creditors where one member of the group provided security for the debts of another group member arise. What would the effect be on the position of the creditor? Which claim survives? The secured claim, the unsecured claim or both? It therefore becomes necessary to investigate a system where consolidation orders are possible. The aim will be to see whether this system provides answers to the questions raised as well as the circumstances under which the consolidation orders are possible. The principles and requirements of the New Zealand system could provide valuable guidelines for South African reform in the field of insolvency of a company within a group/insolvency of a number of companies or even of all the companies within a group of companies.

30. S20(9) of the Companies Act.

31. [2013] 2 All SA 437 (WCC). 


\section{The Position in New Zealand Company Law}

The New Zealand Companies Act ${ }^{32}$ makes provision for (1) a contribution order and (2) a pooling order by the court, in the context of a company within a group structure when it appears to the court that it will be just and equitable to do so. ${ }^{33}$ The court may make a contribution or pooling order on the application of the liquidator, creditor or shareholder of the company. ${ }^{34}$ In deciding whether it is just and equitable to make such a contribution order, the court must take into account a number of factors. These factors are: firstly, the extent to which a related company ${ }^{35}$ participated in the management of the company in liquidation; secondly, the conduct of the related company towards the creditors of the company in liquidation; thirdly, the degree to which the circumstances that gave rise to the liquidation of the company are due to the actions of the related company and, lastly, the court has a discretion to consider any other matter it deems fit. ${ }^{36}$

The requirements which need to be satisfied before a court may order a pooling of the assets of two or more related companies which are in liquidation ${ }^{37}$ are, broadly speaking, the same as the requirements in respect of

32. The New Zealand Companies Act 105 of 1993.

The insolvency law of the United States of America also provides for pooling orders albeit under a different name, that is substantive consolidation orders under the United States Bankruptcy Code - §105(a) provides that " $[t]$ he court may issue any order, process, or judgment that is necessary or appropriate to carry out the provisions of this title. No provision of this title providing for the raising of an issue by a party in interest shall be construed to preclude the court from, sua sponte, taking any action or making any determination necessary or appropriate to enforce or implement court orders or rules, or to prevent an abuse of process." Australian Company law has also recently introduced pooling orders in the context of company groups. The Corporations Amendment (Insolvency) Act of 2007 effected this change into the Corporations Act of 2001. The Corporations Act ss 571-579Q essentially reflects the principles of the New Zealand provisions in respect of pooling orders. One interesting provision is, however, s $579 \mathrm{E}(2)$ (c) which provides that if a pooling order is granted, the effect will be that a claim which one company in a group has against another company in the group will be extinguished.

34. The New Zealand Companies Act s 271(1)(a).

35. The New Zealand Companies Act s1(3) defines a related company as follows: "In this Act, a company is related to another company if-

a. The other company is its holding company or subsidiary; or

b. More than half of the issued shares of the company, other than shares that carry no right to participate beyond a specified amount in a distribution of either profits or capital, is held by the other company and companies related to that other company (whether directly or indirectly, but other than in a fiduciary capacity); or

c. More than half of the issued shares, other than shares that carry no right to participate beyond a specified amount in a distribution of either profits or capital, of each of them is held by members of the other (whether directly or indirectly, but other than in a fiduciary capacity); or

d. The businesses of the companies have been so carried on that the separate business of each company, or a substantial part of it, is not readily identifiable; or

e. There is another company to which both companies are related;and related company has a corresponding meaning.'

36. The New Zealand Companies Act s 272(1).

37. The New Zealand Companies Act s 271(1)(b). contribution orders. The New Zealand Companies Act provides that a court must take certain factors into consideration to determine whether it is just and equitable to grant a pooling order. Firstly, the extent to which any of the related companies took part in the management of any of the other companies; secondly, the conduct of any of the related companies towards the creditors of any of the other companies; thirdly, the extent to which the circumstances that gave rise to the liquidation of any of the related companies are due to the actions of any of the other companies; fourthly, the extent to which the businesses of the related companies have been combined and finally the court is also granted a discretion to consider any other matter as it deems fit. ${ }^{38}$

The New Zealand Companies Act, ${ }^{39}$ which preceded the current New Zealand Companies Act, also provided for the pooling of assets and contribution orders. It accordingly can be assumed that the New Zealand legislature was satisfied with the manner in which the courts applied the provisions of the 1955 Companies Act. The Cork Committee expressed some reservations regarding the position of the creditors of the holding company, for example that they could stand at a disadvantage should the holding company be ordered to make a contribution in respect of the debts of the subsidiary company. ${ }^{40}$ The creditors of the holding company naturally contracted on the basis that the assets of the company will be used only in respect of the claims of that company. ${ }^{41}$ The financial position of a company could drastically deteriorate within a short time due to unforeseen external factors like natural disasters or even man-made disasters, as illustrated by the global credit crunch towards the end of 2008 .

To illustrate the point, assume that holding company $\mathrm{X}$ is in a sound financial position but is ordered to make a contribution of R50 million in respect of the debts of its insolvent subsidiary $\mathrm{Y}$. The net asset value of company $\mathrm{X}$ is reduced by $\mathrm{R} 50$ million but it is still solvent. That position can quickly change due to unforeseen circumstances which will not only prejudice the creditors of company $\mathrm{X}$ but also company $\mathrm{X}$ itself as well as its shareholders. The company's funds have been reduced by the contribution order, which means that there are

38. The New Zealand Companies Act s 272(2). There is, however also a qualification, viz s 272 (3) provides that the mere fact that the creditors of a company in liquidation relied on the fact that another company is or was related to the company in liquidation is not sufficient to grant a contribution or pooling order.

39. The New Zealand Companies Act 53 of 1955.

40. The Cork Committee supra note 1, p. 438, para 1946.

41. The Cork Committee supra note 1, p. 121, the Australian Companies and Securities Advisory Committee in respect of Corporate Groups refers to Farrar 1998, p. 184, who at 197 states "If the contribution sought from a related company threatens that company's solvency, then the court must consider the equities involved affecting the creditors of that company. These creditors will rely on arguments that they have relied on the separate assets of the company when trading with it and should not be denied a full payout because of that company's relationship with another company." Equity to the creditors of the holding company is, however, not the only factor which a court must take into account. In this respect, see the position adopted by the courts in the United States below. 
less funds available for new developments and projects. This could lead to potential job losses and smaller or no dividends for the shareholders of the company. The short-term benefit of assisting the creditors of the subsidiary could have a longer term negative impact, not only on company $\mathrm{X}$ but also on its creditors and other stakeholders like employees and the broader community which depend on it. The ultimate irony would be that the holding company itself is eventually liquidated due to a chain of events which started with a contribution order, even if such order was granted in circumstances which did not cause the immediate parlous financial state of the holding company but was the first little snowball which ultimately became an avalanche resulting in liquidation. ${ }^{42}$

There have not been many cases in New Zealand where pooling orders have been granted by the courts. In $R e$ Dalhoff and King Holdings Ltd, ${ }^{43}$ Dalhoff and King Holdings Limited was a listed company on the New Zealand Stock Exchange. Among its subsidiaries were Dalhoff and King Ltd and D and K Truck Distributors Ltd. All three companies were placed in liquidation. The liquidators of the respective companies applied for a pooling order in terms of the previous New Zealand Companies Act which had a similar wording to the current New Zealand Companies Act. ${ }^{44}$

If the pooling orders were granted, the result would be that the unsecured creditors of the holding company would receive a dividend of 90.88 cents $/ \$$, whereas a refusal to grant a pooling order would mean that the unsecured creditors would receive $1 \$$. The shareholders would receive 28 cents per share in the absence of a pooling order, whereas a pooling order would result in them receiving no dividend. The unsecured creditors of Dalhoff and King Ltd would receive 49.22 cents/\$ in the absence of a pooling order, whereas they would receive 90.88 cents $/ \$$ were the pooling order to be granted. The shareholders in both cases would receive no dividend. In respect of $\mathrm{D}$ and $\mathrm{K}$ Truck Distributors Ltd, the unsecured creditors, like those of the holding company, would be slightly worse off ${ }^{45}$ if the pooling order was granted but in both cases the shareholders would receive no dividend.

At the time of the case, there was little authority on pooling orders in New Zealand. The court referred to the Re Pacific Syndicates (NZ) Ltd ${ }^{46}$ case where all the parties to the case consented to the order and the court did not have to delve into the potential complexities, although the court did allude to them. ${ }^{47}$

42. The counterargument is that the holding company's improper interference in the management of the subsidiary company and insufficient regard for the interests of the subsidiary's creditors led to the insolvency of the subsidiary and ultimately to that of the holding company itself.

43. Re Dalhoff and King Holdings Ltd, NZLR, Vol. 2, 1991, p. 296.

44. Ss 315B and 315C of the New Zealand Companies Act 1955.

45. They would receive 100 cents $/ \$$ in the case of no pooling order and 90.88 cents $\$$ were the order to be granted.

46. Re Pacific Syndicates (NZ) Ltd, NZCLC, Vol. 4, 1989, No. 64, p. 757.

47. Re Pacific Syndicates, supra note 46, pp. 767-768.

48. Re Dalhoff and King Holdings Ltd, supra note 43.
The court in the Dalhoff and King ${ }^{48}$ case held that it had the power to look at the conduct of the parties after the liquidation over and above the statutory requirements which the court needed to take into account. ${ }^{49}$ The first requirement that the court needed to look at was the question of the extent to which any of the involved companies participated in the management of any of the other companies. ${ }^{50}$ From the evidence it was clear that the three companies were de facto operated as a single entity and after the liquidation of the companies the bank account of the holding company was used for all the companies.

The second factor which the court needed to consider in terms of the previous New Zealand Companies Act was the conduct of the companies towards the creditors of any of the companies within the group structure. ${ }^{51}$ Although the number of cases where accounts were not paid by the actual debtor company but by another company was not substantial, the court held that the debts were paid by the entity for whom it was convenient at any particular time. The court therefore held that if the management of the companies treated the companies as one single entity, then so much more would the creditors. ${ }^{52}$ The court held in this regard that:

In summary as to this aspect of the matter, it seems to me that the particular instances clearly establish that the conduct of the companies towards creditors was such as to lead to a degree of confusion on the part of creditors as to which companies were involved with what or whom. A considerable degree of confusion had existed and continued to exist and arises from the continued merged operation of these companies. ${ }^{53}$

The next consideration was to what extent the conduct of one of the companies led to the liquidation of the other companies. ${ }^{54}$ It was clear to the court that the companies 'stood and fell' together and that the demise of one would automatically lead to the demise of the others. ${ }^{55}$ It was however not clear to the court that the conduct of one of the companies necessarily led to the financial difficulties of the other companies, but it accepted that it was 'a matter of common sense' that the actions of one of the companies must have led to the financial difficulties of the other companies. ${ }^{56}$

The next factor which the court had to take into account was the extent to which the businesses of the various companies were combined. ${ }^{57}$ Again the court focused not on individual cases of how the businesses of the var-

49. S $315 C(2)$ of the New Zealand Companies Act 1955 in essence provides that a court has to take into account certain factors which are the same factors as required in s 271(2) of the current New Zealand Companies Act, supra note 26 .

50. S 315C(2)(a) of New Zealand Companies Act 1955.

51. New Zealand Companies Act 1955 s 315C(2)(b)

52. Re Dalhoff and King Holdings Ltd, supra note 43, p. 303

53. Re Dalhoff and King Holdings Ltd, supra note 43, p. 305

54. New Zealand Companies Act 1955 s 315C(2)(c).

55. See supra note 43, p. 305.

56. See supra note 43, p. 305.

57. New Zealand Companies Act 1955 s 315C(2)(d) 
ious companies were commingled but rather on the combined effect which the individual cases had.

The points raised relating to a confusion of ownership in respect of particular assets is a further illustration that the persons responsible for managing the companies did not differentiate carefully between them or their activities, nor does it appear to persons dealing with the companies. [...]. A degree of flexibility has been preserved which may have been convenient for those operating the companies in good times but which is now extremely inconvenient for those whose duty it is to disentangle what has occurred. That difficulty supports the applicants' contentions [that there was an intermingling of the businesses of the various companies]. ${ }^{58}$

The previous New Zealand Companies Act, like the current Act, also enabled a court to take into account other factors which it deemed appropriate or relevant to determine whether or not to grant a pooling order. ${ }^{59}$ The first additional factor which the court considered was the issue relating to the debts within the group of companies and their validity. Were the court to refuse the pooling order, the various debts would have had to be individually scrutinized and allocated to the correct entity. This would be time consuming and lead to uncertainty for the liquidators and the creditors. ${ }^{60}$

The position of the shareholders was also a factor which the court considered. As pointed out above, the pooling of assets would have a significant impact on the shareholders of the holding company since such an order would result in them not receiving any dividends. The previous Companies Act of New Zealand also placed an express duty on a court to take cognisance of the interests of shareholders who are shareholders of only some of the companies in the group and not of all of the companies within the group. ${ }^{61}$ The court held that the purpose of the section was to prevent fraudulent conduct against the shareholders of one company through the conduct of another company within the group structure. Upon the facts in casu there was no intention to defraud or to prefer the shareholders of one company over the shareholders of others. The court held that the sole intention of conducting the businesses as a single entity was one of convenience. ${ }^{62}$ Despite this assessment, the court still held that the shareholders of the holding company should not receive preference over the other shareholders within the group. The court reasoned as follows:

It is true that DK Holdings is a public company but people who purchase shares on the stock market must make their own assessment of the ability and style of

58. Re Dalhoff and King Holdings Ltd, supra note 43, p. 306.

59. New Zealand Companies Act 1955 s 315C(2)(e)

60. Re Dalhoff and King Holdings Ltd, supra note 43, p. 307.

61. New Zealand Companies Act 1955 s 315B. This particular factor has been omitted from s 272(2) of the current Act.

62. Ibid. management in the companies in which they invest, and I do not think that the fact that the shares are publicly traded is a factor which should give a preference to those particular shareholders as distinct from others. ${ }^{63}$

A further relevant factor for the court in respect of the position of shareholders is the balancing of interests of shareholders and creditors of a company in cases of insolvency. With reference to Kinsela $v$. Russell Kinsela Pty Ltd ${ }^{64}$ the court ${ }^{65}$ held that the interests of creditors are more important than those of the shareholders in cases of insolvency. According to the court, section $315 \mathrm{~B}(2)$ of the former Act was there to regulate the relationship between the shareholders inter se and not to find a balance for the competing interests of the shareholders and the creditors of a company. ${ }^{66}$

The relevant section ${ }^{67}$ in the former New Zealand Act, like the current Act, ${ }^{68}$ required the court to be satisfied that it would be just and equitable to grant a pooling order having regard to the relevant factors. The court, having considered the factors discussed above concluded that a pooling order would be apposite in the circumstances:

Taken cumulatively the various matters add up to a formidable case as far as the applicants are concerned. Looked at overall, I think it is apparent that the persons responsible for managing these companies saw them as being separate facets of one enterprise and managed them accordingly dealing with particular situations as was most convenient at the time without reference to strict legal differentiation. [I]t is hardly surprising that members of the public saw the activities of the group of companies in the same way. Justice and equity are terms which would normally involve equality of treatment taking into account all the surrounding circumstances. Against the background of the operations of this group of companies, I think it would be unjust and inequitable both to shareholders and creditors to allow their liquidation separately, thus preferring some fortuitously as against others and, further, separating out activities which have always in the past operated together. ${ }^{69}$

An interesting point which the court also had to consider was the position of one of the creditors who had a claim against one of the subsidiaries. In addition, that

63. Ibid

64. In Kinsela v. Russell Kinsela Pty Ltd 1986 the court held that "where a company is insolvent the interests of the creditors intrude. They become prospectively entitled, through the mechanism of liquidation, to displace the power of shareholders and directors to deal with the company's assets. It is in a practical sense their assets and not the shareholders' assets that, through the medium of the company, are under the management of the directors pending either liquidation, return to solvency, or the imposition of some alternative administration."

65. Re Dalhoff and King Holdings Ltd, supra note 43, pp. 307-308.

66. Re Dalhoff and King Holdings Ltd, supra note 43, p. 308.

67. New Zealand Companies Act 1955 s 315C(2).

68. The New Zealand Companies Act s 271.

69. Re Dalhoff and King Holdings Ltd, supra note 43, p. 309. 
creditor obtained security from the holding company of that subsidiary in the form of guarantee. The creditor under normal circumstances, i.e. in the absence of a pooling order, would have had a claim against both the companies as long as it did not receive a total dividend of above 100 cents/\$. The creditor therefore requested the court to impose a condition to the pooling order in terms of which both claims would be preserved. The court looked at the intention behind the relevant section in the Companies Act and held that the intention behind pooling orders was to confirm the practice whereby various companies were managed as if they were one entity. The court further held that it would not be appropriate to preserve the separate identity of two of the companies in the group so that the creditor still had two claims. This would, according to the court, not be consistent with the order which the court granted. ${ }^{70}$ The court did not, however, accept that there could be appropriate circumstances which could justify the right to preserve different grounds to claim against members of the group. ${ }^{71}$ When one tests the facts of the Botha, Steyn and Zmarts cases against the requirements of the New Zealand Companies Act, read with the application of those requirements in the Dalhoff case, the picture that emerges is one of compliance with the requirements for the pooling or consolidation of the assets and liabilities of the entities under the control of Prinsloo. It is possible that not all the factors are individually complied with but the overall picture is significant and not a simple counting of factors. In the Steyn, Botha and Zmarts cases, it was clear that the various entities were de facto operated as a single entity. Secondly it would appear that to the outside world the scheme was operated under one banner. Internally it was also established that Prinsloo treated the different entities as a single entity. The only problematic issue is whether the conduct of the one entity led to the liquidation of the other entities. As this was a pyramid scheme, it is inevitable that the conduct of Prinsloo in respect of all the entities led to the liquidation of all the entities. Separate books of account were also not kept, and to a large extent therefore there was only one entity. An important factor which the Supreme Court of Appeal raises is the difficulty in separating the assets and liabilities of the different entities in the light of the absence of proper bookkeeping. In the Dalhoff case, the court also mentioned the difficulty, time and uncertainty of a process to unravel and allocate the various debts to the individual entities. The position of the shareholders of the different entities was not as important as in the Dalhoff case

70. Re Dalhoff and King Holdings Ltd, supra note 43, p. 311.

71. Ibid. The court, however, fails to provide such an example. It merely stated: "It is conceivable that in a quite exceptional case reference to the just and equitable aspect of the section might allow sufficient latitude to accommodate the retention of two rights to claim. That is a matter which would have to be determined in an appropriate case. It is my view that the facts of this case do not give rise to any such exceptional situation and I am therefore not prepared to grant the order subject to any condition." See also Gulfco Investment Corporation v. Hogan 593 F.2d 921 (1979), where a similar view was expressed by the United States Court of Appeals, Second Circuit. given the fact that Prinsloo was the driving force behind all the entities. A balancing of interests was therefore not relevant. In sum it could be said that it would have been just and equitable to consolidate the assets and liabilities of the entities within the Krion scheme had it been decided in New Zealand. The issue to be addressed is therefore whether the New Zealand Law on consolidation orders could in some form serve as a basis for reform of the South African Law.

\section{Possible Lessons of New Zealand Law in South Africa}

The New Zealand test of just and equitable is founded on a number of factors including the extent to which the number of companies operates as one entity and whether this fact was what was portrayed to the creditors. The degree of commingling of assets and liabilities and the costs and burden of unscrambling this confusion compared to the advantage for the creditors to incur these costs and the possible time involved are also factors to be considered. However, whether the provisions of the New Zealand Companies Act were applied correctly in the Dalhoff case is debatable. Even if one assumes that it was decided correctly, the dearth of case law in respect of pooling / consolidation orders is maybe indicative that these types of orders are reserved for extreme cases.

The concept of just and equitable is not foreign to company law in South Africa. It is, e.g., used in the context of the liquidation of a company, whether solvent or insolvent. The previous Companies Act ${ }^{72}$ provided that one of the grounds for the winding-up of a company by the court is when the court deemed it just and equitable to do so. ${ }^{73}$ Although a number of categories have developed which led to courts finding that it was just and equitable to order the winding-up of a company, these categories did not form a closed list. In Apco Africa (Pty) Ltd and Another v. Apco Worldwide Inc, ${ }^{74}$ the Supreme Court of Appeal held that section 344(h) of the previous Companies Act granted a court a wide judicial discretion. ${ }^{75}$ Despite this, the majority of cases usually fall within the broad categories of cases where courts are willing to wind up a company on the basis that it is just and equitable. It is submitted that an analogous principle could be established within the context of groups in the light of the provisions of the New Zealand Companies Act, namely that a court may order that the assets and liabilities of companies and/or entities within a group of companies may be consolidated if it appears just and equitable for a court to do so. The court must then take a number of considerations into account which

\footnotetext{
. Companies Act 61 of 1973.

Companies Act 61 of 1973 s 344(h).

74. Apco Africa (Pty) Ltd and Another v. Apco Worldwide Inc, SA, Vol. 5, 2008, p. 615 (SCA)

75. Apco Africa (Pty) Ltd and Another v. Apco Worldwide Inc supra note 74, p. 623 E.
} 
could be similar to the New Zealand Act. Prima facie, it would appear that the corporate veil between the entities is more easily pierced than envisaged by the Act. ${ }^{76} \mathrm{It}$ is however submitted that the common law position in respect of veil piercing and the factors in the New Zealand Companies Act are very close, if not included, under the statutory test.

The insolvency of a group member is one of the situations where the legislature has not adopted any specific provisions which creditors could use to hold the holding company liable for the debts of its insolvent subsidiary. There has been no case law in South Africa where the corporate veil has been pierced between a holding company and a subsidiary to hold the holding company liable for the debts of the insolvent subsidiary company. No case could even be found where this was attempted. Does this therefore mean that the law as it currently stands is insufficient to cover abuses which could take place upon the insolvency of the subsidiary company?

Despite the doubt which has been expressed about the historical foundations for applying the principle of limited liability to company groups, it is a given that the principle was adopted to cater particularly for the situation where the company, in which an investor has invested, fails and goes into insolvency. In such a case, the investor would as a general rule not be liable for the debts of the insolvent company. The principle of limited liability is therefore there on the one hand to stimulate risk-taking. However, as the South African Supreme Court of Appeal mentioned in the Philotex (Pty) Ltd $v$. Snyman; Braitex (Pty) Ltd v. Snyman, ${ }^{77}$ the purpose of business is to take risks but that risk-taking must not be excessive. ${ }^{78}$ Limited liability is, however, a privilege and not an automatic right. It may therefore not be abused and if it is abused, the law provides some remedies in the form of the piercing the corporate veil, although this remedy is rarely granted by a court. It should therefore be asked whether it is necessary to consider a remedy either to replace piercing of the corporate veil or a watered down version of the strict requirements in the context of a group of companies.

In the context of the insolvency of a subsidiary company and the possible liability of its holding company, the issue surrounding liability of the holding company becomes more complex. The creditors of the holding company are exposed in those cases where they contracted with the holding company on the basis that the holding company is a separate entity and not due to its group membership. Where the holding company acts recklessly, fraudulently or otherwise prejudicially towards the creditors of the subsidiary company, the creditors of the subsidiary company may want to hold

76. S 20(9).

77. Philotex (Pty) Ltd v. Snyman; Braitex (Pty) Ltd v. Snyman, SA, Vol. 2, 1998, p. 138 (SCA).

78. Philotex (Pty) Ltd v. Snyman; Braitex (Pty) Ltd v. Snyman, supra note 77, p. 146G, "Participation in business necessarily involves taking entrepreneurial risks but s 424 only penalises the subjection of third parties to risk where (apart from the case of fraudulent trading) it is grossly unreasonable, 146G." the holding company liable for the debts of the insolvent subsidiary. This may however lead to a potential conflict of interests between two sets of creditors; i.e. the creditors of the holding company and the creditors of the subsidiary company. If the holding company is liable for the debts of the insolvent subsidiary, or has to make a contribution or there is a pooling of assets, this will reduce the assets which are available for the creditors of the holding company. ${ }^{79}$ Should any imposition of liability on the holding company specifically have to take into account the interests of the innocent creditors of the holding company or should the court be given a broad discretion based on fairness? The court in Chemical Bank Nem York Trust Company v. Kheel said in this regard:

[E]quity is not helpless to reach a rough approximation of justice to some rather than deny any to all. ${ }^{80}$

Creditors of the different companies within a group may be prejudiced by a consolidation order. Creditors of the holding company should probably be taken into consideration before an order is made in respect of liability for the debts of the insolvent subsidiary company. The only manner in which to determine which creditors deserve more protection is by means of policy considerations. But where does the balance between these policy considerations lie? Equally strong arguments could be made out in respect of the protection of each set of creditors, especially where all of them were innocent participants in the activities of the subsidiary and holding companies. Is there therefore a way to protect each set of creditors and simultaneously to satisfy their competing claims?

There is one provision in South African law where the creditors of a non-insolvent debtor are prejudiced and potential preference is given to the creditors of the actual insolvent debtors. This provision is found in the Insolvency Act. ${ }^{81}$ The Insolvency Act provides that where two parties are married out of community of property and the estate of one spouse is sequestrated, the assets of the other party vest in the trustee of the insolvent spouse, unless the solvent spouse can show that the assets are in fact the assets of that solvent spouse. ${ }^{82}$

The purpose of this provision in the Insolvency Act in respect of the assets of the solvent spouse is to prevent collusion between spouses. ${ }^{83}$ In terms of the common law the trustee had no power to attach the property of the solvent spouse and he had to prove that there was a collusive disposition between the spouses for the purpose of defrauding the creditors of the insolvent spouse,

79. See generally the Cork Committee supra note 1; Re Dalhoff and King Holdings Ltd, supra note 43; and In Re Owens Corning 419 F. 3d 195 (3rd Circuit Delaware 2005).

80. Chemical Bank New York Trust Company v. Kheel 369 F.2d 845 (1966) 847.

81. Insolvency Act 24 of 1936

82. S 21 of the Insolvency Act 24 of 1936.

83. Maudsley's Trustees v. Maudsley 1940 TPD 399; De Villiers NO v. Delta Cables (Pty) Ltd 1992 (1) SA 9 (A). 
where he suspected that the insolvent spouse transferred assets to the solvent spouse. ${ }^{84}$ The trustee of the estate of the insolvent spouse has to release certain property of the solvent spouse. This includes property which belonged to that spouse before marriage, ${ }^{85}$ property acquired under an ante-nuptial contract, ${ }^{86}$ property which the solvent spouse acquired with valid title against the creditors of the insolvent spouse during the marriage ${ }^{87}$ and property which was obtained with the proceeds of the previously mentioned property. ${ }^{88}$ The solvent spouse bears the onus to prove that the property falls within the previously mentioned categories and should be released to him. ${ }^{89}$

The most interesting effect of the provision in respect of the property of the solvent spouse is the one which determines the effect of that spouse's failure to prove that certain assets are her property. ${ }^{90}$ Section $21(5)$ of the Insolvency Act provides that:

Subject to any order [releasing property] made under subsection (4) any property of the solvent spouse realized by the trustee shall bear a proportionate share of the costs of the sequestration as if it were property of the insolvent estate but the separate creditors for value of the solvent spouse having claims which could have been proved against the estate of that spouse if it had been the estate under sequestration, shall be entitled to prove their claims against the estate of the insolvent spouse in the same manner and, except as in this Act is otherwise provided, shall have the same rights and remedies and be subject to the same obligations as if they were creditors of the insolvent estate; and the creditors who have so proved claims shall be entitled to share in the proceeds of the property so realized according to their legal priorities inter se and in priority to the separate creditors of the insolvent estate, but shall not be entitled to share in the separate assets of the insolvent estate.

This provision prima facie appears to be nonsensical. It in essence provides that if the solvent spouse cannot prove that assets belong to her, the trustee of the insolvent spouse may realize these assets. The proceeds of the assets are however for the satisfaction of the claims of the creditors of the solvent spouse. If the solvent spouse could not prove that the assets belong to her, why should her creditors then be paid from these assets? ${ }^{91}$ The provision still exists despite this contradiction. What it does however provide is the recognition that dispositions between related parties are realities and that they are very difficult to prove, which is detrimental to the creditors of an insolvent person. The shifting

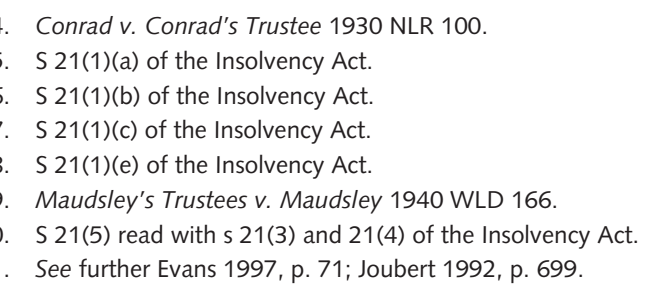

of the onus of proof to the solvent spouse to prove that the assets belong to her is an attempt to safeguard the interests of the creditors of the insolvent party, which relieves them from the burden of proving that there was a collusive disposition. By analogy, one could consider the feasibility of a similar type of provision within the context of a company group. One could conceivably use the factors which are listed in the New Zealand Companies Act as a point of departure. Should a creditor of an insolvent prove any of the factors, there would be a rebuttable presumption that the group of companies is a single entity. One could also consider that where one of the companies is in liquidation, especially where it is a subsidiary, that the assets of the holding company and/ or of other solvent companies within the group could be attached by the liquidator of the insolvent company. If the solvent company/ies fail(s) to show that those assets are indeed its/theirs, those assets can be used to pay creditors of the insolvent group member.

There are therefore provisions in South African law, although inelegantly and contradictorily drafted, which attempt to reconcile the interests of the competing creditors of spouses. The question is whether this could be a workable solution in the context of a group of companies. As mentioned before, the aim of section 21 of the Insolvency Act is to prevent collusive dealings between spouses and the difficulty facing creditors of the insolvent spouse to prove such collusive dealings. It is submitted that the same difficulties would not necessarily be present in the context of a company group. In the first place, the subsidiary may be obviously undercapitalized and own very few assets which it can dispose of. Secondly, profits would have been declared and paid to the shareholders. A paper trail of asset movement would make collusion more difficult to conceal in a group situation than between spouses. A rebuttable presumption or a provision shifting the onus of proof could, however, be helpful to assist creditors of the insolvent subsidiary in those cases where there is no paper trail of transactions between companies within a group of companies.

\section{Conclusion}

Milo is of the opinion that any liability will have to be imposed by means of legislation on the holding company, since the piercing of the corporate veil doctrine, agency argument and partnership argument are too vague or uncertain. ${ }^{92}$ Milo suggests that there should be a presumption that the holding company ignored or did not respect the separate identity of the subsidiary. This presumption rests on the basis that the principle of limited liability is not necessarily desirable and can therefore be ignored as a point of departure. If the holding company succeeds in discharging this presumption, the Salomon principle will apply. ${ }^{93}$ The justification for

92. Milo 1998

93. Milo 1998, p. 344. 
the presumption which Milo advocates corresponds to the argument that limited liability is a historical accident in respect of company groups and that the economic justification of the principle is not necessarily convincing in respect of company groups. ${ }^{94}$

It is submitted that the traditional piercing of the corporate veil test also has not brought any clarity as to when the corporate veil will be pierced. It is submitted that the statutory piercing of the veil test ${ }^{95}$ does not adequately address this uncertainty either. It is therefore proposed that a system similar to the pooling and contribution orders in New Zealand law be introduced. What could be done to temper an abuse of such system is to have a system similar to the regime of section 21(5) of the Insolvency law, namely that there should be a presumption in favour of a pooling/consolidation order if certain factors are present. These factors could be the factors listed in the New Zealand Act. The onus would then be on the holding company to show why consolidation should not take place. This suggestion would not destroy the principle of limited liability but only place restrictions on it. The point of departure would therefore still be the separate juristic personality of all the entities within the group. It is submitted therefore that the liquidation provisions of the Companies Act should be amended to reflect this possibility. In respect of intra-group debts and the issue of securities of creditors against one entity in the group and the survival of the main claim against the principal debtor, it is submitted that the court should exercise its inherent discretion to make an appropriate order in this regard.

\section{Bibliography}

P.I. Blumberg, The Multinational Challenge to Corporation Lam, 1993.

J.B. Cilliers \& S.M. Luiz, "The Corporate Veil - An Unnecessarily Confining Corset?", THRHR, 1996.

R. Evans, "A Critical Analysis of the Section 21 of the Insolvency Act 24 of 1936", 60 THRHR, 1997.

J.H. Farrar, "Legal Issues Involving Corporate Groups", 16 Companies and Securities Lam Fournal, 1998.

N. Joubert, "Artikel 21 van die Insolvensiewet: Tyd vir 'n nuwe benadering", $T S A R, 1992$.

D. Milo, "The Liability of a Holding Company for the Debts of Its Insolvent Subsidiary: Is Salomon Still Alive and Well?", 115 SALF, 1998.

A. Muscat, The Liability of the Holding Company for the Debts of Its Insolvent Subsidiaries, 1996.

R. Stevens, The External Relations of Company Groups in South African Law: A Critical Comparative Analysis, LLD Dissertation, United States, 2011. 